\title{
1959 Institute for California Judges - Panel Discussion, Part II: Selecting the Jury
}

The California Law Review presents herewith the second of a series of three panel discussions presented at the Institute for California Judges. The publication of the discussions has been undertaken in the hope that their presentation in printed form will expand their usefulness to the participants and make them available for the first time to the bar in general. The Institute was conducted under the sponsorship of the Conference of California Judges and the School of Law, University of California, Berkeley, June 15-17, 1959, in the Moot Court Room of the School of Law. The first panel discussion, entitled "Preliminary Matters and Trial Proceedings," appeared in the October issue. The third and concluding panel, entitled "Instructing the Jury," appears in this issue following the panel printed below. Participants in the panel on "Selecting the Jury," were as follows:

The Honorable Stanley Mosk, Attorney General, State of California; former Judge of the Superior Court, Los Angeles County

Joseph Bali, Past President, State Bar of California; Attorney at Law, Long Beach

Arthur H. Sherry, Professor of Law and Criminology, School of Law, University of California, Berkeley

The record of the proceedings was edited by Thomas $H$. Gee of the California Law Review staff.

MR. BALL: I think that throughout the United States there is a generally accepted view that jurors will be questioned prior to being accepted. In England they take the jury and put them in a box and swear them and go ahead and try the law suit. In the federal system the judge questions the jury, but there is a great variety in procedure in the different federal courts. Some federal judges will permit counsel to ask questions directly. Others require that questions be submitted in writing 24 to 48 hours before the trial. In other courts the judge just goes ahead and questions the jury himself. Some ten States including Massachusetts and Pennsylvania follow this latter system, in which counsel does not have the right to question the jury.

In California we use a modified system in which the judge questions the jurors first and then counsel is permitted to interrogate. Twenty-nine States follow this rule. Eleven of the fifty States allow unrestricted questioning by counsel with the judge taking no part. I personally favor the California system. I guess we've all had the experience of trying cases in front of judges who permit unrestricted examination, and I think it's a great waste of time. 
The reason we question the jurors is to find if they have any actual or implied bias or if there are other reasons why they are undesirable as jurors. The judge alone cannot, in my experience, determine these things, bcause the jurors are sliy people. They come into a new area, they sit in the jury box, they look upon the judge as a great man, and they are afraid of hin. It takes a rather resolute juror to speak out when the judge asks questions of the whole panel and says to speak up if there are any differences of opinion. If you were there, you would not speak up, and I know I would not either because we do not like to call attention to ourselves. It is only when counsel questions the jurors individually that it can be discovered if there is bias. However, an unrestricted examination of jurors is a great waste of time. There should be a liberal right of counsel to ask pertinent questions, but certainly not the right to waste everybody's time by asking questions which have no bearing on the issues.

This brings us to a second field of controversy that I find among trial judges, and that is as to what purposes counsel should be permitted to ask questions. I suppose you have all read People v. Edwards, ${ }^{1}$ in which the court said that the purpose of examining jurors is to determine facts as a basis for the exercise of a challenge for cause and not to gather information for a peremptory challenge. I think the custom throughout California is not in accord with this strict rule. The courts in two more recent cases have said that it is proper to question either for a challenge for cause or as a basis for peremptory cliallenge. Those cases are Walker v. Greenberger ${ }^{2}$ and People v. Boorman. ${ }^{3}$ It is my belief that throughout California the courts have followed the liberal rule of the Walker and Boorman cases.

ATTY. GEN. MOSK: Mr. Ball's point that the British system does not permit any interrogation of jurors emphasized the point that I think we should begin with, and that is an effort to improve the caliber of jurors. It is true that we do have an opportunity to interrogate the jurors in California, but the manner of selecting a jury for impanelment in this State should be critically evaluated, as it seems to me to be of prime importance. I am sure you all have been struck by the occupations of the jurors who are called to fill our jury boxes each trial. They are either women or retired men for the most part. You seldom get an actual accurate cross-section of occupations and age groups in the community. I think the judiciary, particularly, and the organized bar ought to make greater efforts toward obtaining the cooperation of business enterprises, corporations, umions and others in subsidizing their employees who are called as jurors, i.e., to continue to

\footnotetext{
1163 Cal. 752, 127 Pac. 58 (1912).

263 Cal. App. 2d 457, 147 P.2d 105 (1944).

${ }^{3} 142$ Cal. App. 2d 85, 297 P.2d 741 (1956).
} 
pay them their regular wage during the period of jury service. If we do that we will also eliminate the so-called professional juror, the person who is serving on the jury because he needs the job and wants the money. That kind of person is not going to be a very good juror.

The second subject suggested as a topic for discussion is whether there ought to be a pamphlet of instructions given to the jury panel. This is done in southern California, and I think that such a book or pamphlet is good on the whole. It should be carefully prepared and should have the approval of both plaintiff's and defendant's counsel and of prosecutor and defense counsel in criminal cases. However, I do not think that the pamphlet is a good substitute for a lecture by the presiding judge at the time the jury panel is first called to acquaint it first hand with the problems of a trial. In that lecture I think the judge must be very elementary. He cannot assume the panel even knows the meaning of such basic terms as "plaintiff," "defendant," "indictment," or how a case conies into court in the first place. Further, I think it is important that the judge in starting the proceedings and taking over the voir dire examination describe the type of case to the jurors and give sonie details about it. Then the judge should ask the jurorsen banc, of course-whether they know any of the parties involved and whether they have seen or heard or read anything about the incident involved. The lawyers should then be introduced to the nuembers of the jury panel and/or to the jurors in the box, and the jurors should be asked if they know any of the lawyers. At this point you will find that one or two of the group will indicate that they know one of the lawyers by virtue of having tried a case in which the lawyer was involved, perhaps a week or two before. I would suggest that these jurors be asked whether their impression from the lawyer's action in the prior case would prevent them from giving his client in this case a fair and impartial trial. All jurors should then be asked if the particular kind of case before them, whether it is personal injury, criminal or of any other nature, causes thein to have an immediate prejudice either for or against the plaintiff or defendant. If the case is a criminal case, they should be asked whether or not they are peace officers or directly related to persons who are peace officers. They should be asked whether or not they are related to persons who are engaged in the defense of criminal cases. They should also be asked en banc whether or not they are in the insurance business or have any connection with the insurance business, the judge making it clear, however, that no insurance company is a party to the action. These types of general questions, it seems to me, can be asked en banc. The problems arise when counsel begin individual questioning. There frequently is a tendency after a judge has covered all of the above subjects for counsel to repeat these questions to the individual jurors. Now, with due respect to Mr. Ball's point that perhaps no one is going to 
raise his hand and respond to the judge's interrogation and that he might, thereafter, respond to the attorney's interrogation individually, I do think, however, that it is unnecessary to permit counsel to repeat all of these questions or even a substantial part of them. The question is, what do you do if counsel is going to do it anyway? Frequently a lawyer will repeat the same questions that you have asked and do it over and over again to each one of the twelve jurors. Well, I think under those circumstances that timely admonition is adequate. Certainly no lawyer likes to be adinonished in the presence of the jury. It would reflect upon his standing, and jurors are frequently looking for a clue as to how the judge feels about the case. I think that just a timely adınonition will prevent unnecessary repetition of questions by cousel.

PROF. SHERRY: One subject that I think we might devote our attention to, so far as the jury is concerned, is the inpingement of press, radio and television on the conduct of trials. As you know, we have an increasing problem in litigation, chiefly criminal, of adjusting the right to a fair trial against the press's claim of its undoubted right to freedom of the press. This problem has been met in one way in England by simply excluding comment by the press until after the trial. We have had several cases in this country where press interference with the conduct of the trial has resulted in reversal. For the most part, however, appellate courts have been rather reluctant to reverse in this area, perhaps feeling that it does not do much good and that it is not going to change our mode of existence.

All judges know, of course, that apart from this problem, jurors must serve on a case with a coinpletely unbiased and open mind. So many times I have heard the judge at the outset of the trial admonish the jury, in addition to the usual warning not to discuss the case among themselves, not to read newspaper accounts of the trial and not to listen to radio or television accounts of the trial. Jurors by their silence ordinarily, I suppose, assent to this adinonition. But how effective is it really? In some jurisdictions jurors are as a matter of course locked up once they are impaneled, no matter what kind of a case it is. Here, it is only in the extraordinary case that the juror will be sequestered during a trial, usually only in those situations where some direct threat to the freedom of the jury in involved, such as intimidation or endeavors to approach or corrupt the jury. How can we meet this problem? How can we be sure that the jurors are not going to be influenced by newspapers, radio and television? You can picture a casethis actually occurred-in which there is an issue during the trial as to whether or not a confession should be admitted. The confession is excluded by the court on the ground that it is not voluntary. Thereupon the jurors leave the courthouse and facing them on the news stands as they get out of 
the elevators are the big headlines, "Defendant's confession excluded!" I do not think you can tell anybody that an individual, whose guilt is in question, has confessed, without shifting the balance a little bit in his mind.

A related problem is that of protecting the jury after the trial. It seems to be almost customary now for newsinen to interrogate the jurors after a case is over and ask them how they voted and why they voted as they did. Why should jurors be exposed to this kind of thing? If they are going to be interrogated when they leave the courtrooin as to how they voted, they are in effect being held accountable to the public for what they did. I do not think this is in harmony with the spirit of a jury trial or any other kind of a trial for that matter. Judges do not permit themselves to be interrogated when they act without a jury. I have never heard a judge explain his result to the press, defensively or otherwise. I feel we ought to do something to prevent jurors from being so interrogated.

MR. BALL: Does a judge have the right to prevent people from questioning jurors afterwards? Whether desirable or not, does he have the right?

ATTY. GEN. MOSK: I think he ought to make it pretty clear to the jurors that they have no obligation to respond to questions from anyone, whether it is counsel or press or friends or anyone else. On the other hand, it should be made clear to them that they are free citizens when they leave the courtroom and can say anything they choose. The right to freedom of speech guarantees that. But they are under no obligation of any kind to answer questions. If you emphasize that enough, perhaps it will have some effect.

QUESTION: How much of the questioning of individual jurors is to create rapport between the attorney and the juror?

MR. BALL: I know that a good many trial lawyers use this as a part of their technique in selecting a juror, and I have been guilty of it myself, but I have more or less modified my ideas as to its value. First of all, I am not sure that during a trial the juror does get sufficient opportunity from observing the lawyer and how he handles himself in the courtroom to form an opinion as to whether he dislikes or admires him. Secondly, I think that if we do pursue these tactics and consequently take a lot of time, we may lose the very valuable right as trial lawyers to individually question the jurors. I think that questions should be pertinent. They should not be asked simply to get acquainted with the juror.

QUESTION: Do you think the judge should permit a juror to be asked. questions on matters of law? 
MR. BALL: There has been a controversy in this State through the years whether you should permit such questions or whether you should permit just a few questions like where do you hve, what's your name, what's your age, etc. I beheve it is essential when you question jurors to ask some questions about law; e.g., in a personal injury case I think it is proper to ask a juror whether, if he were instructed upon the doctrine of contributory negligence, he would follow it. I say this because I think that a good many people have come to believe that it would be desirable to apply a rule of comparative negligence rather than contributory negligence. I think that is the trend among the people, and yet we try these cases on the contributory negligence rule. Because of this, I think it is necessary that the jurors be asked if they would follow that rule. In criminal cases, if self-defense is an issue, I think it is wise for defense counsel to ask the jurors if they have any prejudice against the law of self-defense. Similarly, there frequently exists a prejudice against the law of insanity. Of course, the question asked by the district attorney as to prejudice against the death penalty is always permitted.

ATTY. GEN. MOSK: I have some reservations about such questioning. I have seen a lawyer take his proposed jury instructions and thumb through them, page by page, in forming his questions to the prospective jurors. $\mathrm{He}$ was trying to imstruct them in the law. It has always been my policy to call him to the bench the first time and protest that I am going to instruct the jury in the law after the case is submitted and that I do not feel it is his province to instruct the jury in the law in connection with voir dire examination. It may be that one or two fundamental questions are appropriate, such as self-defense. But even when you permit a question on contributory negligence, you will find that usually the lawyer, in framing the question, will omit one or two elements of the legal definition. If he is asking about contributory negligence, he will inevitably omit proximate cause; the other counsel will interpose an objection, and you have to rule immediately whether the question does include all of the elements of the law involved. I think interrogation on the law in the voir dire examination is fraught with too many dangers and too much controversy.

MR. BALL: In the case of People v. Bennett, ${ }^{4}$ Justice Hart took two or three pages to explain that certain fundamental problems-reasonable doubt, presumption of innocence and self-defense-are proper subjects for questioning on voir dire, and he held it was improper to sustain an objection to such questioning. This case was cited with approval by Justice Shenk in People v. Tuthill, ${ }^{5}$ which upheld the right of the district attorney to 
question on matters of law. The case of People v. Modell $l^{\complement}$ supports your statement, Judge Mosk, that questions on jury instructions per se should not be permitted. I heartily agree. We cannot permit unrestricted questions on problems of law, but I am talking about certain areas of law which are fundamental to the issue and against which there is a suspicion or popular prejudice.

ATTY. GEN. MOSK: Every case you have cited was a criminal case. Do you have any.civil cases?

MR. BALL: I have one civil case, Kramm v. Stockton Electric R.R., ${ }^{7}$ but it is mostly in criminal cases that these problems come up.

QUESTION (Judge Lawson-Monterey Counly): I am interested in the modus operandi of interrogating jurors. I have served in both southern and northern California and I notice some diversity. For example, in southern California, or at least in some departments in Los Angeles County, the practice is to have the judge interrogate and then have the plaintiff's attorney interrogate the entire panel, asking all his questions of them. Following this, the defense attorney questions the entire twelve and if he raises new material the plaintiff's attorney may be permitted to interrogate further. In northern California the practice generally is to have questions asked of the first juror by plaintiff's attorney, followed by questions to the same juror by defendant's attorney with interrogation continuing in this manner through the entire panel. I would like Mr. Ball's opinion as an attorney as to which method is preferable.

MR. BALL: I prefer as a matter of custom the questioning of the twelve because that is the system under which I have practiced. It is the custom all through southern California. Under the alternating or individual questioning system if you once question a juror and do not immediately challenge that juror for cause, you waive your challenge for cause when you move to the next juror. We question all twelve jurors and then we can challenge for cause any one of them.

ATTY. GEN. MOSK: I rather like the southern system because I think it expedites the selection of the jury, but I know that a lot of the attorneys who have practiced before me do not like it. That is because they are not educated to asking questions properly, and instead of addressing their 
questions to the entire jury, a lot of them try to go one by one through the twrelve and then they become embarrassed because they are repeating the questions too many times.

MR. BALL: I have found that same embarrassment. There are certain key questions that you want to ask every juror. I have attempted to solve that embarrassment by asking a key question of one person directly, and then I will deliberately stand and say, "Now I'm not going to ask that question again, but I want an answer. Now if you or you or you, any of you, answer differently, hold up your hand, don't answer, just hold up your hand."

FROM THE FLOOR: I also prefer interrogating the whole jury. Often the attorney may desire to establish a pattern for the jury as a whole which he will not be able to ascertain by individual interrogation. He can get a better picture of the complexion of the jury and can, perliaps, better form in his own mind what use to make of peremptory challenges if he has the answers to all of his questions from all of the jurors before exercising any challenges.

JUDGE QUAYLE (Alameda County): I think there is something to be said for the procedure of interrogating the jurors individually both by plaintiff and the defendant and then exercising a challenge for cause at that time. The challenges for cause are unlimited, so I do not see how it helps to wait to exercise them at once. I have found that our system enables the attorney to keep im mind the particular imdividual being interrogated. Very often, where the plaintiff eventually exercises a challenge for cause, it is for something the defendant has brought out in his examination of the juror. The attorneys focus on a particular juror until they are satisfied that he is not subject to a challenge for cause.

FROM THE FLOOR: Under this system where you take one juror at a time, suppose the plaintiff and the defendant have examined and accepted a particular juror. Then, as the examination progresses it develops that one of the attorneys forgot to ask a question and he would now like to ask it. Under this system he cannot go back at that point and ask this question. I think that is perhaps one of the advantages of the system of having each attorney examine all the jurors before exercising any challenge. New ideas develop during the examination and the attorney will very often want to go back and ask juror number one the question which was suggested to him by number ten. I think that a lot of lawyers feel they can evaluate the indi- 
vidual juror better after all twelve have been questioned even for a challenge for cause.

QUESTION: Do you have any trouble in remembering the basis of a challenge for cause? In other words, suppose you have gone through twelve jurors and examined them all, and now you want to challenge number one. Do you have the ground for challenge well enough in mind?

ATTY. GEN. MOSK: I found that even in the system that is used in southern California where one attorney interrogates all twelve jurors first, if a challenge for cause arises, usually the attorney makes that challenge immediately. Nornally I will rule on it at once. The challenge for cause is generally immediately apparent. There seldom is any argument.

QUESTION: Should we provide counsel with more information from the clerk's or jury commissioner's files regarding the jury panel?

MR. BALL: I have practiced in certain counties outside of Los Angeles County, which have a list of the panel in the courtroom, giving the name, age, occupation and address of each member. I do not know how many counties do this, but I find it very helpful. In Los Angeles County, the only way we can get such information is by buying a jury book.

QUESTION: How many counties have for sale jury books which contain a record of the vote of jurors in each case?

JUDGE ST. CLAIR (San Francisco): We have them in San Francisco. One of the practices that irritates me is that the girl who is collecting information follows the jury around and sits in the front row in court. I am sure those jurors cannot be on niore than one jury before they know what that girl is doing there. I do not know what the effect is, but it cannot be good because they act as though sle is spying on them or following them up. I wonder if other counties have the same problem.

JUDGE QUAYLE: In Alameda County we have the same problem, and the jurors resent it very much. They come to the judges and complain that their life is an open book and that people are checking on them constantly. One of the chief complaints of jurors is the feeling of being watched by people who seem to be trying to find something in their background to be exposed on the voir dire as ground for a challenge.

FROM THE FLOOR: I tried a few years ago to get some corrective legislation on this subject, but the jury book publishers had a better lobby 
than I did and my measure did not succeed. In your opening reniarks you talked about jurors being accountable. The jurors do feel accountable. Some of them have been frank enough to say that because of the jury book they felt they alniost had an obligation to even up their verdicts during the course of service on the juries-so many for the plaintiffs and so many for the defendants-so that they would not be arbitrarily challenged as being a plamtiff's juror or a defendant's juror. This is rather frightening. My first inclination was to bar jury books from my courtroont. I was going to do it and suggest that somebody challenge it if he did not like the idea. But I had delegations of plaintiffs' lawyers come to me and say this would put them at a disadvantage because insurance company counsel would keep these records and pass them out among themselves if the books were barred in the courtroom. The only way a plaintiff's lawyer can get this mforniation is to purchase it. So I didn't arbitrarily bar them, but I do announce to counsel before each trial that if either side makes a motion to bar the jury books from the courtroom on the ground that they are an undue influence upon jurors, I will either grant the motion or sustain the objection to the use of the jury book. I do this out of the presence of the jury, of course. I have never had anybody object, and it has been held that the use of the books was not reversible error. ${ }^{8}$ But there have been no decisions holding that sustaining an objection to the use of the books would be error. I have a feeling that it would not be error to sustain an objection to the use of the books.

FROM THE FLOOR: The biggest complaint that I have is in the jurors being polled. I have had jurors conie up to ne and want to know why they were polled after their verdict was returned. I think they tied it in with seeing these people record all their history in these books. Actually the jurybook people do not have to sit in the courtroom, and a lot of them do not in our courts. They can get all that information if they want from the clerks and the reporters, and certainly they should be excluded from the courtroom during the questioning of the jury. We do not have this problem in the mumicipal courts because the jurors do not sit that often, but in the superior court, where the jurors are continually moved from one department to the other, these people follow then around from court to court and the jurors begin to know it.

MR. BALL: I would like to know if anybody thinks the jury book does any good. What is the merit of the jury book? I thimk I could do without one. I always buy one because I have to. But in the main I do not think you

8 Baugh v. Beatty, 91 Cal. App. 2d 786, 205 P.2d 671 (1949). 
can bet on a juror like you can on a horse. I have never been sold on jury books, personally.

QUESTION: By section 1076 of the Penal Code ${ }^{9}$ a juror is not disqualified by reason of having formed an opinion from what he may have read in the newspaper or heard over the radio if he says that he can put that opinion aside and decide the case solely on the evidence. Do you think a judge should excuse such a juror on his own motion?

MR. BALL: I remember reading in the newspapers about the Duncan case in Ventura County, and I understand that after the defense had exhausted the peremptory challenges, one or two jurors were in the box who stated they had an opinion as to the guilt of the defendant which they had gained from reading newspapers, and these jurors renained to try the case. I have always considered the answer by jurors that they can put their opinion aside a calculable fraud committed in order to sit on the jury. If a person says he has an opinion that the defendant is guilty, I do not think he ought to sit on the jury, especially on a death penalty case. Yet the Code section is directly against my position. What would be the position of you judges who sit here? Would you blindly follow the Code section and try to justify the retention of these jurors?

JUDGE REPPY (Ventura County): That is what happened in the Duncan case. After the defense had exhausted its peremptories, there were jurors left who stated they did have an opinion about the case. But everybody liad an opinion about that case in Ventura County. I am well satisfied, having discussed the matter with Judge Blackstock, who tried the case, that lie did not make his rulings in an arbitrary manner. He exercised his discretion as he did, not only because that was the rule but also because he was satisfied that the jurors being questioned were of the type and caliber that could probably do what they said they would as nearly as any individual can.

JUDGE SIMS (Municipal Court, Central District, Marin County): Perhaps the statute is a recognition of the fact that the person who will come out and admit to having an opinion is the one honest fellow you have on the jury and the other eleven wlio deny they have an opinion are the ones you would not want anyway.

9 CAI. PEN. CODE $\S 1076:$ "[N]o person shall be disqualified as a juror by reason of having formed or expressed an opinion upon the matter or cause to be submitted to such jury, founded upon public rumor, statements in public journals, circulars or other hiterature, or common notoriety; provided it appear to the court, upon his declaration, under oath or otherwise, that he can and will, notwithstanding such an opmion, act impartially and fairly upon the matters to be submitted to him." 
MR BALL: It seems to me that the defense should never have to start out with a handicap like that. I have always been opposed to the Code section as a matter of principle. I don't see any necessity for it. But the legislature has spoken, and we have to follow it. However, a great deal of discretion, it seems to me, rests with the judge in determining whether there is such bias in a juror's mind that he should not sit. The judge does have the discretion to excuse on his own motion if he wants to. I think you all realize that this is your right. If I were a trial judge and this problem faced me, especially in a death penalty case, I would be reluctant to permit a juror to sit, no matter what he says.

JUDGE HEATON (Ventura Municipal Court): I might say that I have always erred on the side of excusing anybody admitting to an opinion, the Code section notwithstanding. No matter how honest you are, if you recognize your prejudices you either are going to lean too far backward or yield to the prejudice, and it is an embarrassing and difficult position for anybody who recognizes it. As a consequence, I think it is almost impossible for a juror in that position to be fair, and I would like to relieve him of the responsibility.

MR. BALL: In civil cases, it is traditional that anybody you respect on the other side will say immediately when anything like that comes up, "We stipulate to excuse." That is traditional. Why should it be any different in criminal cases?

FROM THE FLOOR: I have seen this offer of a stipulation to excuse a juror abused much too often. Such an offer puts opposing counsel in a very embarrassing position and enables one man to use a dozen challenges instead of his six or ten as the case may be. When someone does not like a juror, and he feels that he does not have enough challenges, he will offer to stipulate to excuse. That can happen in such ways as to make it almost impossible for the other attorney to avoid making the stipulation. I have arbitrarily for the last year or so invoked the rule that when counsel have a stipulation on any subject, whether it is the excusing of a juror or as to an exhibit or anything else, that they discuss it among themselves out of the hearing of the jury and present it to me only when it is a stipulation and not an offer of stipulation. I find it helps move things along and prevents what I consider simply histrionics in the courtroom to try to gain an object which could not otherwise be gained. 
FROM THE FLOOR: I would say it all depends on the type of case and the temperament of the court and county. In San Diego it may be 1 hour in one court and 2 hours in another. In a first degree murder case I would say an average of 2 to 3 hours.

JUDGE LEVIN (San Francisco): I am in a criminal department in San Francisco, and I would say the average is an hour to an hour and a half, excepting a murder case.

FROM THE FLOOR: My experience when I was sitting in the superior court in San Francisco was an hour. In municipal court we get them in less than an hour.

FROM THE FLOOR: In San Mateo it takes about an hour or an hour and a half in general.

FROM THE FLOOR: Speaking for a so-called cow county, with no jury commissioner, I would say it would be closer to 2 hours.

PROF. SHERRY: A jury commissioner undoubtedly does make a difference in the rate in which a jury is selected. He weeds out, of course, or should weed out, most of those obviously unqualified.

FROM THE FLOOR: In Tulare County, I would say it takes about 2 hours in the average case-not to exceed 2 hours.

JUDGE REPPY : In Ventura County we have a jury commissioner, and it still takes 2 hours.

JUDGE LAWSON: We have a jury commissioner in Monterey County and we take an average of about an hour. I also take care of San Benito County, which is a cow county, and they have no jury commissioner, and there you are lucky if you get one by $2: 30$ in the afternoon. You have to work hard because of the lack of information. So many are excused for cause, too, because of local knowledge.

JUDGE CARKEET (Tuolumne County): We have that problem in Tuolumne County, too; it's a cow county and we are fortunate if we get a jury by $2: 00$ or $2: 30$ in the afternoon because of local relationships, local knowledge and lack of a jury commissioner.

FROM THE FLOOR: In the superior court in Los Angeles it takes until noon, at least, in a civil case, and in a criminal case usually less than that. Probably an hour on the average criminal case. 
QUESTION: What are your views of the practice of starting a trial in a municipal court, usually in a misdemeanor case, with a fractional jury, i.e., agreeing by stipulation to take a jury of only six members?

PROF. SHERRY: I have not heard of the practice myself, but I suppose all of us have had the experience of suddenly finding one juror ill after a case had started and having a stipnlation to go ahead with the eleven remaining. That is not so unusual.

FROM THE FLOOR: If they are willing to shorten up by taking six only, I do not see the necessity of the judge or anybody else requiring twelve.

PROF. SHERRY: Is this a practice in your courts?

FROM THE FLOOR: No. We recently experimented with it. We are just starting it. It is a substantial time-saver.

FROM THE FLOOR: Do you require the defendant, if it is a criminal case, to stipulate to the fractional jury as well as his attorney?

FROM THE FLOOR: Yes.

FROM THE FLOOR: It seems to me the six-man jury is a bad practice to start, because what you are doing is lessening the gravity of a criminal offense in a municipal court. If a person is on trial for a 502 [Vehicle Code, revised section 23102, Misdemeanor Drunk Driving] or for any other misdemeanor where he may be incarcerated, a full jury of twelve should be the rule unless the legislature changes the law.

FROM THE FLOOR: The law says that you may waive it altogether so why not just waive it part way?

JUDGE GRIFFITH (Los Angeles Municipal Court): I do not feel it is necessary for a defendant to have twelve jurors in a jury trial of a minor traffic offense. There should be a constitutional amendment giving authority to the legislature to reduce the number of jurors in these cases to less than twelve. It should not require twelve persons to decide, for example, whether or not the defendant failed to stop his vehicle for a red light or a boulevard stop. In Los Angeles we are heavily burdened with traffic trials. More than 100,000 citations are issued to traffic offenders each month by the Los Angeles Police Department, and quite a few of those people are asking for jury trials. A reduction in the present number of jurors in each 
minor traffic offense triable by jury would certainly mean a great savings to taxpayers.

Violations of Vehicle Code sections 502 [revised section 23102, Misdemeanor Drunk Driving], 332 [revised section 14601, Driving When License Refused, Suspended or Revoked], 483 [revised section 20007, Hit and Run-Unattended Vehicle] and such other sections are misdemeanors serious in their consequences, while the consequences for violations of minor vehicle offenses are usually no more than a small fine. I can see no necessity for a defendant to be guaranteed the right to a trial by twelve jurors for a minor traffic offense. I think six would be adequate.

PROF. SHERRY: I think that is actually the rule in some jurisdictions, although I cannot identify any at the moment.

PROF. HAZARD (School of Law, University of Cahfornia, Berkeley): Under Oregon law they use six in the misdemeanor trials. In fact, that is the norm. You can demand a standard jury trial but it is made procedurally difficult to get the twelve.

FROM THE FLOOR: The State Senate Judiciary Committee is making a study of this as a result of the State bar's interest in it.

FROM THE FLOOR: My principal question was as to whether we are treading on any constitutional privileges even if we get the stipulations.

PROF. SHERRY: I should not think so, in view of the other southern California practice of trying cases on a preliminary transcript.

QUESTION: Some aspects of this problem have already been discussed, but what steps are being taken to insulate the jurry from press and other outside influences during the trial?

JUDGE ST. CLAIR (San Francisco County): This is a very sore subject with us. In San Francisco we have no place for the jurors during intermissions, and they stand in the corridors. In those corridors are not only the touts and investigators for both sides but also the jury book people. There is absolutely no protection whatever, and the innocent juror can be just as much influenced by a staged conversation nearly in which he is not involved as by being directly approached. I know these things happen in our corridors, and it is a very serious problein. Occasionally in civil cases we lock up a jury, and of course we lock them up in a criminal case. Otherwise all we can do is hope to have physical facilities where we can semi-protect them. 
MR. BALL: We send them to the jury room in Los Angeles County. In criminal cases we do it regularly and also in most civil cases, so that during the recesses the juries are isolated from the public. When they come in, they report to the jury room, and they are kept there when not in court until they are discharged at noon. They report back to the jury room after lunch and they stay there until court reconvenes.

JUDGE MEYERS (Tulare County): In Tulare County we send them into the jury room at all recesses with the admonition not to discuss the case given while the public is in the courtroom. We feel that is about as far as we can go. We are a smaller county and do not have the problem that you do in the larger areas.

FROM THE FLOOR: In Ventura County we do much the same as Tulare. The jury goes to the jury room during recesses, but for lunch and evening recesses they are on their own.

PROF. SHERRY: Of course, if the trial goes more than a day and the jurors are excused and permitted to go to their honies overmight or over a weekend or holiday, it is pretty hard to expect that they are not going to be exposed to some outside influences.

FROM THE FLOOR: I make it a practice to advise the jurors that the admonition not to discuss the case with anyone specifically includes their spouses.

FROM THE FLOOR: Because of an unfortunate experience I have had in this connection, I direct the jurors to bring to the court's attention any attempts to influence them or any occasion when others spoke in their presence concerning the trial. I have had occasion in one instance to declare a mistrial because the plaintiff's wife displayed the defendant's criminal record in a civil case in the corridor among the jurors. I thought that justice required the declaration of mistrial when such matter was brought to the attention of the jurors. I think that this additional admonition to the jurors in the presence of the spectators will tend to curtail any such attenipts or acts.

PROF. SHERRY: When this sort of thing comes to the attention of the court, it can lock the barn door by declaring a mistrial and going out and looking for another horse, I guess. But you still do not get to the problent of really insulating the jury during the course of the trial. I do not suppose it can be fully accomplished, short of locking them up, and it is my own experience, at least, that this is very rarely done. 